\title{
Infiltration Rate Assessment of Coastal Plain (Ultisols) Soils for Sustainable Crop Production in the Frontiers of Calabar-Nigeria
}

\author{
EGBAI ORUK O., UQUETAN, UQUETAN IBOR EWA, EWA E., NDIK, ERIC J. \\ Department of Geography and Regional Planning, University of Calabar, Calabar - Nigeria \\ Tel: 234-070-6702-0808 E-mail: egbaioruk@yahoo.com \\ OKEKE, O. FRANCIS \\ Wildlife Conservation Society (WCS), Calabar-Nigeria \\ Tel: 234-803-065-2799 E-mail:fokeke@wcs.org
}

Received: December 19, 2010

Accepted: January 20, 2011

doi:10.5539/jsd.v4n4p222

\begin{abstract}
The study on infiltration rate assessment of coastal plain soils for sustainable crop production in the frontiers of Calabar, Nigeria, was carried out in order to examine the infiltration rate of soils in the area and its implication in the overall crop production process. Double ring infiltrometer were driven at $5 \mathrm{~cm}$ into the soil with the aid of a sledge hammer before water was poured simultaneously into the rings. Infiltration rates were taken at 5,10,15, and 30 minutes intervals. The assessment or determination of infiltration rate was preceded by laboratory analysis of soil samples for the particle size distribution. The mean values of 74.0, 12.0: and 12.6 for sand, silt and clay were obtained respectively. While infiltration rates were well above the recommended values for crop production. Result from different locations proved that the area has monolithic soil characteristics. The result equally showed that the least range of infiltration rate of 14.4-60.0 was well above the optimal range of 0.7-3.5 or the suitable infiltration range of 3.5 - 7.5. It would be said, that, given the increasing need for food production to cope with the demand in Calabar Metropolis, the effect of excessive water infiltration as evidence in this study, will continue to impede sustainable crop production except appropriate measures are contemplated. These measures may include adequate cover cropping, temporary abandonment of farm land or skeletal crop farming with compost, green or farmyard manures. This will help improve the structure and restore soil potentials. Apart from these, suitability evaluation of land in order to effectively categorize soils on the basis of their potential for optimal use could as well be imperative.
\end{abstract}

Keywords: Infiltration rate assessment, Coastal plain soils, Sustainable crop production

\section{Introduction}

Precipitation, upon falling on the soil surface, wets it, fills depressions and penetrates into the soil. This water replenishes the soil moisture deficiency with the excess moving downward by force of gravity through seepages or percolation to build up the water table Diamond (2004). The phenomenon of infiltration has been variously defined; it entails a process of water movement from surface soil into the ground. This water is said to have the potentials of penetrating into the lower soil profile (Marshall, 2002; shanley, 2004). Besides, it carries with it some amount of nutrients (Rattan et al, 2005, Chhonkar et al 2005).

Thus, when soils are impoverished or have excessive increase in volume or amount of water that percolates through the horizons, the danger it poses is not only the interference with soil moisture content but in the enhancement or cascade of plant nutrients and consequently creating unfavourable condition for sustainable crop production (Alasto et al, 2008). Infiltration problem may be misconstrued for lack of adequate soil nutrient a situation that usually accounts for uncontrolled or unguided use of agrochemicals to facilitate crop growth and development (Popov et al, 2005, Hartemink, 2006). The use of organic and inorganic fertilizers to remedy this condition was experimented (Turk et al, 2006, Riley et al, 2008).

Infiltration of water into the soil has important impact in the overall functioning of the variable land - based activities. It has significant tradeoffs for environmental sustainability, food security, biodiversity stability and susceptibility of soil to adverse environmental conditions. Two factors can greatly undermine availability of water for sustainable crops production viz: low water table and impervious layer. The former may be due to excessive infiltration which is often a function of soil characteristic while the later may be largely due to clay deposit that can cause crusting below the soil surface.

In recent times, frontiers of Calabar Metropolis have witnessed tremendous decline in food production capacity. This is as a result of the widespread disillusionment with the unproductive nature of the soil (Akoroda 1994; Opeke 2005) on one hand and unguided human activities (Andry et al., 2007) on the other. These activities can 
undermine soil productivity (voorhes and Lindstrom, 1984; Blackwell et al., 1985; Allegre et al., 1986; Hartge, 1988; Hillel, 1982).

The above scenarios are capable of suggesting obvious set back to the overall crop production process. Hence, the soil can no longer support crop growth since their natural integrity has been badly threatened. The specific effects of soil compaction on sustainable crop production has been considered (Thurow et al., 1988; Wood et al., 1989; Takar et al., 1990 ) consequently, food items are now bought to complement as well as bridge the supply-demand gap in the area.

Prior to this development, the affected area(s) was indeed the main stay of food production need, until recently when crop production efforts have been inadvertently disrupted, such that cases of excessive leaching as well as erosion perturbation have now assumed a no less dimension. Apparently, the phenomena of soil erosion and leaching of nutrients are largely attributed to lack of sufficient vegetative cover. It is the vegetation that offers protection to soil from the direct impact of rain drop, percolation and prevents easy detachment and transportation of soil materials due to runoff. Exposing soil surfaces to the vagaries of weather elements often produce detrimental effect hence, the major cause of bare land condition. Black and Burn (1984) had noticed alteration in infiltration rate in bare land area.

The assessment of infiltration rate is considered as an important area of research (Warran et al., 1986) especially in the face of obvious land cover changes and demographic pressure. The letter is responsible for the overt miss-use of land resources (Lambin et al, 2003) and soil area decrease (Lepers et al, 2005). Because of crop water relation, there exists a strong connection between infiltration capacities of soil with sustainable crop production. Thus, crop production can be impeded when infiltration is in excess or too small as to encourage normal microbial activity in the soil. The production of crops on a sustainable bases hinges on adequate or sufficient quantity of water that can guarantee crop growth and development.

Hypothetically, infiltration rates of the affected areas are not significantly different in spite of variation in experimental locations. This implies that certain parts of the landscape can adequately suit crop production. Objective included the determination of infiltration rate of the coastal plain (Ultisols) soil and its implication on sustainable crops production in the area.

\section{The Characteristic of the Area and Method of the Study}

The study area includes Obufa Esuk Orok, Edim Otop and Atimbo Districts. These are located within the periphery of Calabar Metropolis between longitude $8^{0} 19^{\circ} \mathrm{E}$, and latitude $4^{\circ} 58^{\circ} \mathrm{N}$ (Figure 1).

The geology of the area comprises the tertiary sandy deposits of

fluvio-Marin origin which are overlain by quaternary silty and clayey alluvian, eroded from Oban hills in the outskirts. This characteristic poorly consolidated none cohesive and porous rock formation permits large accumulation of ground water with slight variation in rain fall regime. The annual average rainfall is about $2000 \mathrm{~mm}$ (Ayoade, (2004). Temperature rarely falls below $19^{\circ} \mathrm{C}$ and an average of $27^{\circ} \mathrm{C}$ all over the year. The relative humidity is usually between $80-100$ per cent and avapour pressure in the air averaging $29 \mathrm{~m}$ bars throughout the year. Agriculture is the dominant occupation of the people with variation

in agricultural landuse. This includes: Oil palm plantation, livestock farm, cassava, maize and a variety of other crops that are grown in the area.

The infiltration rate was determined by double ring infiltrometer (inner ring $30 \mathrm{~cm}$ and outer ring $50 \mathrm{~cm}$ diameter, each $30 \mathrm{~cm}$ high) were driven at $5 \mathrm{~cm}$ into the soil with the aid of a sledge hammer. Care was taken to ensure minimum disturbance to the soil. Water was poured simultaneously in both inner and outer rings to a depth of $10 \mathrm{~cm}$. this level was maintained throughout the runs. The inclusion of outer ring was to ensure that the water movement in the inner ring was vertically downward. This served as a buffer for maintaining hydrostatic equilibrium. Precaution was taken while pouring water into the inner ring in order to prevent damage to the soil structure. (Philip, 1957; Landon, 1991).

Infiltration rates were taken at the intervals of $5,10,15$ and 30 minutes respectively. This process was made to continue for 180 minutes. According to Philip (1957) it is necessary to continue until a steady state is reached (at least for 3 hours).

Principally, three sites were chosen for this study, Obufa Esuk Orok, Atimbo and Edim Otop all lying around the periphery of Calabar Metropolis (Fig 1). These locations were chosen on the bases of a large proportion of farming population attracted by huge agricultural lands potential coupled with Great Quo River(for irrigation purposes) that is surrounds greater part of the land. Soil samples were collected using auger at a depth of (0 $15 \mathrm{~cm})$ this was subjected to laboratory analysis for particle size distribution.

\section{Result and Discussion}

Tables 1,2 and 3 show the particles size characteristics of these areas. The region has a monolithlogic sedimentary characteristic.

These tables show mean values of soil physical properties of the various locations. The textural analysis revealed that soils are predominantly sandy loam. 
From this finding it could be inferred that soils of this area have similar physical properties. The statistical comparisons of the mean values of soils particles size distribution revealed that there is no significance difference in the soils of the various locations.

The respective plots in these various locations are all within the same environmental setting and have therefore about the same set of geomorphological terrain, soil type and climatic variation, they are therefore expected to have similar infiltration rate. As a result, high rate of infiltration is possible. Consequently, even though the rain water percolates into subsurface aquifer, but cannot be held by the soil pores for long. Surplus water flows into channels and form water regimes that flow directly to Quo River which lies adjacent to the area (Fig. 1).

Similar results were earlier obtained in the area (Antigha, 2007) while other authors had earlier reported similar results elsewhere (Shanley,2004; Tilman, 2001).

Several factors affect infiltration rate of a given soil, these include: soil type (that is, physical properties of the soil), rainfall, vegetation cover, original moisture content of the soils prior to the time of investigation.

From the result in Tables 4, 5 and 6 indicating data on infiltration, it would be said that there was widespread percolation of water into the soil throughout the period of experiment. Although, there was a seeming dragging at the later part of the experiment owing to possible saturation of pore spaces. Two things can be adduced from the result (in tables 4,5 and 6). The effect of weathering may have had heavy toll on the area such that both the soil organic matter (SOM) and clay fraction that supposedly prevent massive seepage of soil water including nutrients may have been adversely affected. Thus, enhancing steady infiltration of water and soil nutrients in the event of rainfall until it reaches a point of interference which is usually unimaginably right deep the soil horizon. This is capable of causing water stress for crops growth and consequently the main reason for low crop production in recent times. From the result it is possible to have a greater chunk of water that enters the soil drains off soon after the rains.

It is important to note that although from the result, one can make a generalized statement regarding the infiltration rate of the area without taking into cognizance the unobtrusive but intriguing differences. For example, tables 4, 5 and 6 showed significant increases at the initial stage of the experiment but maintained seeming decreases at the rest part of the infiltration runs. The infiltration rate increased continuously after runs 1-3 in all the locations indicating that the soil pores were not saturated thus, water holding capacity is at its lowest ebb. This suggests that there was no serious impediment such as reasonable amount of clay or sufficient organic matter content that could have prevented excessive cascade of fluid. To this end, after 15 minute interval water started seeping gradually until a steady state was reached.

However, in table 4, the infiltration rate was lowest at the last two runs (at 30 minute interval) indicating 0.25 and 0.26 respectively. While table 5 showed steady infiltration rate at 5,10 and 15 minute interval as indicated by $0.46,0.50$ and 0.60 , respectively. In table 6 , there was stability at 0.26 and 0.33 . This dynamics or differences in infiltration rates as shown in the tables above may be due to impervious layer (clay deposit right down the soil depth) which is capable of interfering with smooth seepage of water into the soil. Obviously, the infiltration rate of the study area is too rapid when compared to Landon (1991) prescribed infiltration values of $0.7-3.5 \mathrm{~cm} / \mathrm{hr}$ as optimal and $3.5-6.5 \mathrm{~cm} / \mathrm{hr}$ as suitable infiltration rates (Table 7). Hence, the need to employ appropriate soil restoration mechanics that will forester sustainable crop production.

It would be said, that, given the increasing need for food production to cope with the demand of the ever growing population of Calabar Metropolis, the effect of excessive soil water infiltration as evidence in this study, will continue to pose great concern except appropriate steps are taken to halt the trend. These steps may include adequate cover cropping, skeletal crop farming with compost, green or farmyard manure (Glisic and Milosevic,2009; Jelic et al., 2007; Sulieman and Buchroithner, 2008) or temporary abandonment of farm land (Abubaker, 1996; Wezel and Haigis, 2000; Wezel and haigis, 2002). This would engender humus production which has important significance in crop production process (Lal, 2006). Crop production is usually favoured under soil condition where erosion, leaching and infiltration rates are moderate in order not to undermine its production process.

\section{Conclusion}

Progress in agriculture is always impeded following an outright neglect or abandonment of the basic principles and practices that can forester significant and result oriented crop production possibilities.

The study has revealed a large scale infiltration rate. Thus the least figure as portrayed in the study is well above Landon (1991) ideal ranges. This implies that, the soils are quite susceptible to high rate of infiltration, hence, the main reason for low crop yield in the area in recent times. This will require the application of environmentally friendly measures that can help cushion the effect of excess infiltration and thereby ensure sustainable crop production.

\section{References}

Abubakar, S. M. (1996). Rehabilitation of Degraded Lands by means of Fallowing in the semi-arid Area of Northern Nigeria. Land Degradation and Development (7) 133-144. 
Allegre, J. C., Cassel, D. K. and Brandy, D. E. (1986). Effect of Land Clearing on Subsequent Management of Soil Physical Properties. Soil Sci. Soc. Am. J. (50)1379-1384.

Andry, H. Yamamoto, T \& Inove, M. (2007). Effectiveness of hydrated time and artificial Zeolite amendments and sedum (sedum sediforme) plant cover in controlling soil erosion fron an acid soil. Australian Journal of soil research 45: 266-279.

Antigha. N.R.B. and Essien I.E. (2007) The Relationship between infiltration rate and Hydraulic Conductivity of some soils of Akpabuyo Local Government Area, Cross River state- Nigeria: Global Journal of pure and Applied science 6:2.

Ayoade, J.O. (2004). Introduction to climatology, for the tropic. Ibadan, Spectrum Books limited.

Blackburn, W. H. (1984). Impact of Grazing Intensity and Specialized Grazing Systems on Watershed Characteristics and Responses. Pp927-985. In: National Research Council. Developing Strategiesss for Rangeland Management. West view Press Boulder Co.

Blackwell, P.J., M.A. Ward, R.N. Lefevre, and D.J. Cowan. (1985). Campaction of a swelling clay soil by agricultural traffic: effects upon conditions for growth of winter cereals and evidence for some recovery of structure. J Soil Sci. 36: 633-650

Chhonkar, P.K., Bhadrary, S. \& Purakayastha, T.J. (2005). Phytore-mediation of heavy metal contaminated soils. Monographs, Dehion of soil science \& Agriculatural chemistry, IARI, New Delhi.

Diamond, ,J. (2004). Bulk Density Determination of Chlonroche Country

Soil. Irish Geography (36)2.

Don-scott, H. (2000). Soil Physics. Agricultural Environmental Application;Iowa, State University Press.

Glisic, I. P \& Miloservic, T. M. (2009). The effect of natural Zeolitis and organic fertilizers on the characteristics of degraded soils and yield of crops growth in Western Serbia. Land Degrad. Develop 20:33-40.

Hartge, H. K. (1988). The Problem of Compaction on Agricultural lands. Applied Geography and Development (32) 44-50.

Hartmink, A.E (2006). Assessing soil fertility decline in the tropics using soil chemical data. Advances in Agronomy 89:179-225.

Hillel, D. (1980). Introduction to Soil Physics. Academic Press Inc. New York, USA.

Jelic, M. Zivanovic - Katic, S. Milivojevic, J. Nikolic, O. (2007). The effect of liming to charge of PH valued and content of mobile $\mathrm{Al}$ in vertisol type. Ecological Truth 1:242-246.

Lal, R. (2006). Enhancing crop yields in the developing countries through restoration of the soil organic carbon pool in agricultural lands. Land degradation \& Development 17:197-209.

Lambin, E. F., Geist, H. J. and Lepers, E. (2003).Dynamics of Land-use and Land-Cover Change in Tropical Regions. Annual Review of Environment and Resources (28) 205-241

Landon, J, R. (1991). Brooker Tropical Soil Manual, Washington, Longman Scientific and Technical.

Lepers, E. Lambin, E.F. Janetos, A.C., Defreces R., Archard, F., Raman Kutty, N. \& Scholes, R. J. (2005). A syntesis of information on rapid land cover change for the period $1981-200$. Bioscience 55: $115-124$.

Marshal, T. J. (2002). Soil Physics. Cambridge, Cambridge University Press.

Masto, R. E, \& Chhonkar, P.R., Purakayaslha, T. J, Patra, A. K. \& Singh, D. (2008). Soil quality indices for evaluate of crop term land use and soil management practices in semi-arid sub-tropical India. Land Degrad. Develop. 19:516-526.

Philips, 3. R. (1957). The Theory of infiltration. The Infiltration Equation and its Solution. Soil Science (83) 4.

Popov, V. H. Cornish, P.S., Sultana, K. \& Morris, E. C. (2005). Atrazine degradation in soils. The role microbial communities atrizine application history, and soil carbon. Austracian Journal of soil Research 43:861-871.

Rattan, R.K. Datta, S. P., Chhonkar, P.K. Suribabu, K. and Sing, A. K. (2005). Long-term impact of irrigation with sewage effluents on heavy metal content in soils, crops and groundwater a case study. Agriculture, Ecosystems \& Environment 109:310 - 322.

Riley, H. Pommeresche, R. Ettun, R. Hansen, S. \& Korsaeth, A. (2008). Soil structure organic matter and earthwarm activity in a comparison of cropping systems with contrasting tillage, rotations, fertilizer levels and manure use. Agriculture, Ecosystems \& Environment 124:275-284.

Shanley, T. (2004). Infiltration Rate Assessment of Soils Capacity to accept Rainfall.

Sulieman, H. M. Buchroithner, M. F. (2009). Degradation and Abandonment of mechanized rain fed agricultural land in the Southern Gadarif region, Sudan: The local farmer perception. Land Degrad. Develop 20:199-2009.

Takar, A.A., J.P. Dobrowlski, and T.L. Thurow. (1990). Influence of grazing, vegetation life-form, and soil type on infiltration rates and inter- on Somalion rangeland. J. of Range Manag. 43(6): 486 - rill erosion 490. 
Thurow, T.L., W.H. Blackburn, and C.A. Taylor Jr. (1988). Infiltration and linterril erosion response to selected livestock grazing strategies, Edwards Plateu, Texas. J. of Range Manag. 41(4): 296-302.

Tilman, D. (2001). Forecasting Agriculturally driven Global Environmental Change. Science (292) 284.

Turk, K. M. Bayram, G., Budakli, E. and Celik, M. (2006). A study on effects of different mixtures of zeolite with soil rates on some yield on parameters of alfalfa (Medicago sativa L.). Journal of Agronomy 5:118-121.

Voorhes, W. B. and Lindstorm, M. J. (1984). Long-Term Effects of Tillage on soil Tilth Independent on Wheel Traffic Compaction. Sci. Soc. Am. J. (48) 152-156

Warren, S. D. , Blackburn, W. H. and Taylor, C. A. (1986). Effect of Season and Stage of Rotation Cycle on Hydrological Condition of Rangeland under Intersive Rotation Grazing. J. of Range Manag.39 (6) 486-491

Wezel, A. and Haigis, J. (2000). Farmer Perception of Vegetation Changes in semi-arid Niger. Land Degradation and Development (11) 523-534.

Wezel, A. and Haigis, J. (2002). Fallow Cultivation System and F armers' Resource Management in Niger, West Africa. Land Degradation and Development (13) 221-231

Wood, J.C., W.H. Blackburn, H.A. Pearson, and T.K. Hunter. (1989). Infiltration and runoff water quality response to silvicultural and grazing treatments on a longleaf pine forest. J. of Range Manag. 42(5): 378-381.

Table 1. Soil Physical Characteristic of Obufa Esuk Orok

\begin{tabular}{|l|l|l|l|l|l|}
\hline S/N & SAMPLE POINTS & SAND & SILT & CLAY & TEXTURE \\
\hline 1. & A & 78.0 & 10.0 & 12.0 & SL \\
\hline 2. & B & 77.0 & 11.0 & 12.0 & SL \\
\hline 3. & C & 77.0 & 12.0 & 11.0 & SL \\
\hline 4, & D & 75.0 & 120 & 13.0 & SL \\
\hline 5. & E & 74.0 & 11.0 & 15.0 & SL \\
\hline RANGE & & $\begin{array}{l}74-78 \\
=76\end{array}$ & $\begin{array}{l}10-12 \\
=11\end{array}$ & $\begin{array}{l}11-15 \\
=13\end{array}$ & SL \\
\hline
\end{tabular}

\section{Source: Field work (2010)}

Table 2. Soil Physical Characteristic of Edim Otop

\begin{tabular}{|l|l|l|l|l|l|}
\hline S/N & SAMPLE POINTS & SAND & SILT & CLAY & TEXTURE \\
\hline 1. & A & 72.0 & 12.0 & 16.0 & SL \\
\hline 2. & B & 78.0 & 12.0 & 9.0 & SL \\
\hline 3. & C & 75.0 & 14.0 & 11.0 & SL \\
\hline 4. & D & 77.0 & 13.0 & 10.0 & SL \\
\hline 5. & E & 76.0 & 9 & 15.0 & SL \\
\hline RANGE & & $\begin{array}{l}72-78 \\
=75\end{array}$ & $\begin{array}{l}9-14 \\
=11.0\end{array}$ & $\begin{array}{l}9-15 \\
=12.0\end{array}$ & SL \\
\hline
\end{tabular}

\section{Source: Field work (2010)}

Table 3. Soil Physical Characteristic Of Atimbo Area

\begin{tabular}{|l|l|l|l|l|l|}
\hline S/N & SAMPLE POINTS & SAND & SILT & CLAY & TEXTURE \\
\hline 1. & A & 68,0 & 17,0 & 15.0 & SL \\
\hline 2, & B & 78.0 & 12.0 & 10.0 & SL \\
\hline 3. & C & 78.0 & 12,0 & 10.0 & SL \\
\hline 4, & D & 69.0 & 16,0 & 17.0 & SL \\
\hline 5, & E & 72.0 & 13.0 & 17.0 & SL \\
\hline RANGE & & $68-78$ & $12-17$ & $17-0$ & $\begin{array}{l}\text { SL } \\
\bullet J \\
\bullet-\end{array}$ \\
\hline MEAN & & & & 13.0 & \\
\hline
\end{tabular}

Source: Field work (2010) 
Table 4. Infiltration Rate of Obufa Esuk Orok

\begin{tabular}{|c|c|c|c|c|}
\hline Interval (mins) & $\begin{array}{|ll|}\text { Cumulative } & \text { Time } \\
(\mathrm{m})\end{array}$ & $\begin{array}{l}\text { Cumulative Intake } \\
(\mathrm{cm})\end{array}$ & $\begin{array}{l}\text { Infiltration Rate } \\
\text { Intake/cum. }\end{array}$ & $\begin{array}{l}\text { Infiltration Rate } x \\
60 \mathrm{~cm} / \mathrm{hr} \text {. }\end{array}$ \\
\hline 0 & 0 & 0 & 0 & 0 \\
\hline 5 & 5 & 5.00 & 1.00 & 60.00 \\
\hline 5 & 10 & 9.00 & 0.90 & 54.00 \\
\hline 5 & 15 & 10.60 & 0.70 & 42.00 \\
\hline 5 & 20 & 12.40 & 0.62 & 37.20 \\
\hline 5 & 25 & 13.80 & 0.55 & 38.00 \\
\hline 5 & 30 & 16.00 & 0.53 & 31.80 \\
\hline 10 & 40 & 20.40 & 0.51 & 30.60 \\
\hline 10 & 50 & 24.00 & 0,48 & 28.80 \\
\hline 10 & 60 & 25.00 & 0.43 & 25.80 \\
\hline 15 & 75 & 28.10 & 0.37 & 22.20 \\
\hline 15 & 90 & 30.00 & 0.33 & 19.80 \\
\hline 30 & 120 & 34.00 & 0.28 & 16.80 \\
\hline 30 & 150 & 39.00 & 0.26 & 15.60 \\
\hline 30 & 180 & 44.50 & 0.25 & 15.00 \\
\hline
\end{tabular}

Source: Field work (2010)

Table 5. Infiltration Rate Of Edim Otop

\begin{tabular}{|l|l|l|l|l|}
\hline $\begin{array}{l}\text { Interval } \\
(\mathrm{mins})\end{array}$ & $\begin{array}{l}\text { Cumulative } \\
\text { Time }(\mathrm{m})\end{array}$ & $\begin{array}{l}\text { Cumulative Intake } \\
(\mathrm{cm})\end{array}$ & $\begin{array}{l}\text { Infiltration Rate } \\
\text { Intake/cum. Time }\end{array}$ & $\begin{array}{l}\text { Infiltrationb Rate x } \\
\mathrm{cm} / \mathrm{hr} .\end{array}$ \\
\hline 0 & 0 & 0 & 0 & 0 \\
\hline 5 & 5 & 5 & 1.00 & 60.00 \\
\hline 5 & 10 & 10 & 1.00 & 60.00 \\
\hline 5 & 15 & 10 & 0.66 & 39.60 \\
\hline 5 & 20 & 10 & 0.60 & 36.00 \\
\hline 5 & 25 & 15 & 0.60 & 36.00 \\
\hline 5 & 30 & 18 & 0.60 & 36.00 \\
\hline 10 & 40 & 20 & 0.50 & 30.00 \\
\hline 10 & 50 & 25 & 0.50 & 30.00 \\
\hline 10 & 60 & 28 & 0.46 & 27.60 \\
\hline 15 & 75 & 35 & 0.46 & 27.60 \\
\hline 15 & 90 & 37 & 0.41 & 24.60 \\
\hline 30 & 120 & 41 & 0.44 & 26.40 \\
\hline 30 & 150 & 44 & 0.29 & 17.40 \\
\hline 30 & 180 & 46 & 0.25 & 15.00 \\
\hline
\end{tabular}

Source: Field work (2010) 
Table 6. Infiltration Rate of Atimbo

\begin{tabular}{|c|c|c|c|c|}
\hline $\begin{array}{l}\text { Interval } \\
\text { (mins) }\end{array}$ & $\begin{array}{l}\text { Cumulative } \\
\text { Time }(\mathrm{m})\end{array}$ & $\begin{array}{l}\text { Cumulative Intake } \\
(\mathrm{cm})\end{array}$ & $\begin{array}{l}\text { Infiltration Rate } \\
\text { Intake/cum. Time }\end{array}$ & $\begin{array}{l}\text { Infiltration Rate } x \\
60 \mathrm{~cm} / \mathrm{hr} \text {. }\end{array}$ \\
\hline 0 & 0 & 0 & 0 & 0 \\
\hline 5 & 5 & 5 & 1.00 & 60.00 \\
\hline 5 & 10 & 9 & 0.90 & 54.00 \\
\hline 5 & 15 & 11.60 & 0.73 & 46.80 \\
\hline 5 & 20 & 12.60 & 0.63 & 37.80 \\
\hline 5 & 25 & 12.90 & 0.52 & 31.20 \\
\hline 5 & 30 & 13.20 & 0.44 & 26.40 \\
\hline 10 & 40 & 15.50 & 0.39 & 23.40 \\
\hline $10 \mathrm{a}$ & 50 & 16.50 & 0.33 & 19.80 \\
\hline 10 & 60 & 20.20 & 0.33 & 19.80 \\
\hline 15 & 75 & 22.40 & 0.30 & 18.00 \\
\hline 15 & 90 & 25.70 & 0.29 & 17.40 \\
\hline 30 & 120 & 30.80 & 0.26 & 15.00 \\
\hline 30 & 150 & 40.00 & 0.26 & 15.60 \\
\hline 30 & 180 & 43.20 & 0.24 & 14.40 \\
\hline
\end{tabular}

Source: Field work (2010)

\section{Ratings of infiltrations rate for surface irrigation}

\begin{tabular}{|l|l|}
\hline Basic infiltration rate $\mathrm{cm} / \mathrm{hr}$ & Sustainability for surface irrigation. \\
\hline$<0.1$ & Unsuitable (too slow) but suitable for rice \\
\hline $0.1-0.3$ & Marginally suitable (too slow), marginally suitable for rice \\
\hline $0.3-0.7$ & Suitable; unsuitable for rice \\
\hline $0.7-3.5$ & Optimum \\
\hline $3.5-6.5$ & Suitable \\
\hline $6.5-12.5$ & Marginally suitable (too rapid) small basin Reflowed \\
\hline $12.5-25.0$ & Suitable only under special condition very small basins reflowed \\
\hline$>25$. & Unsuitable (too rapid) recommended for \\
\hline & overhead method only \\
\hline
\end{tabular}

(Source: Landon, 1991) 


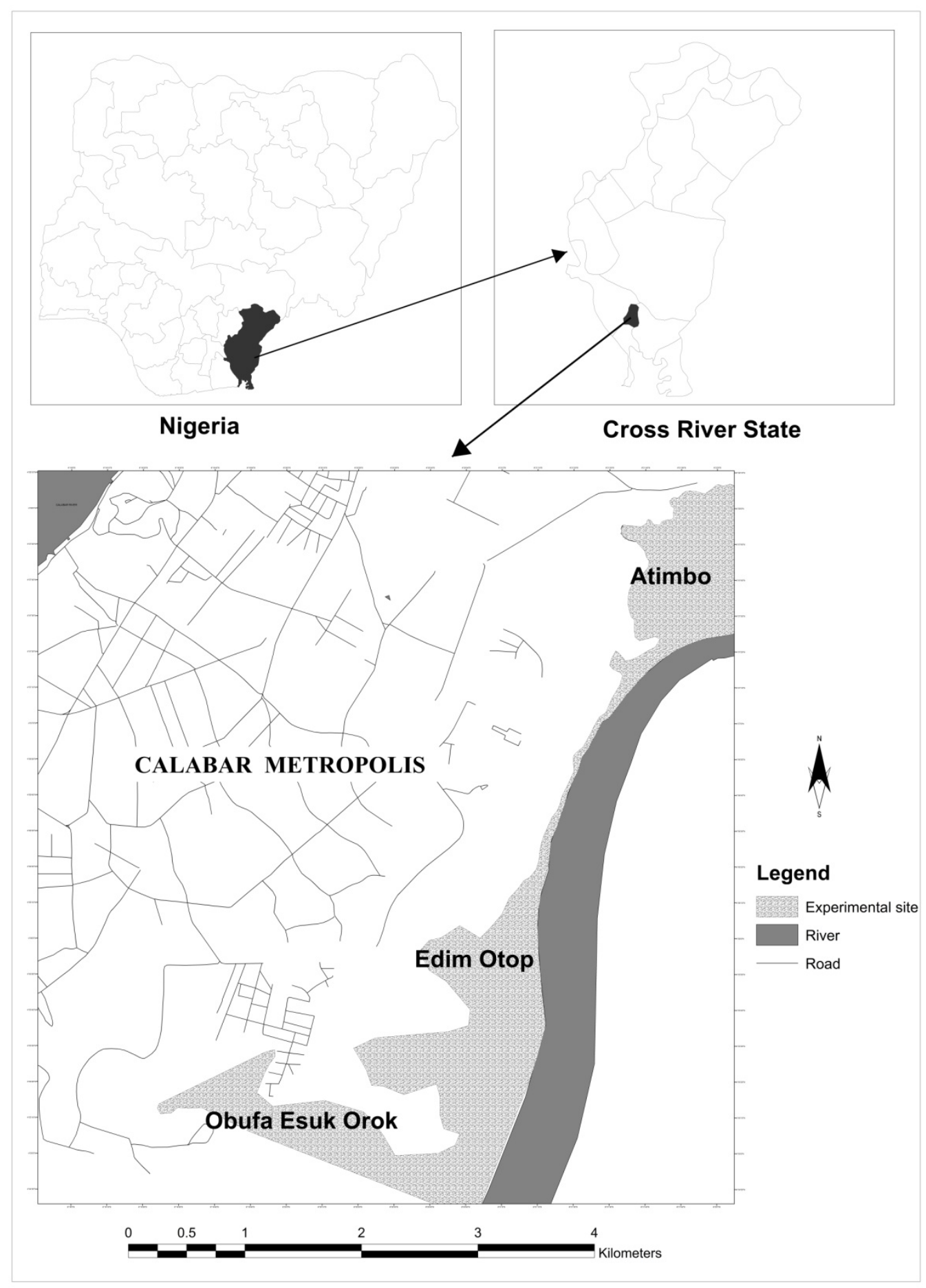

Figure 1. showing map of the study area 